\title{
Media Coverage of Current Political Situation in Ukraine: Discourse Analysis
}

\author{
Anastasia V. Kolmogorova \\ and Yulia A. Gornostaeva* \\ Siberian Federal University \\ 79 Svobodny, Krasnoyarsk, 660041, Russia
}

Received 26.01.2016, received in revised form 24.03.2016, accepted 17.06.2016

The research looks at the manipulation in political media discourse. The purpose is to investigate media coverage of current political situation in Ukraine by analyzing Western and Russian articles from such sources as 'the Russia Today', 'the Washington Post', 'The New York Times', 'The Daily Mail' etc. In the present study we have based on the T.A. van Dijk's theory and we have done contextual and textual discourse analysis of the chosen articles. The analysis has shown that journalists tend to use the strategy of negative other-presentation with the help of lexical units with negative connotation. Moreover, they use the means of coreference to put all and the same referents in a favorable or unfavorable light. It is also noticed that often Russian media try to represent the Ukrainian army as 'violent extremist organizations', 'pro-Nazis' or 'fascists'. The Western articles are full of military terminology because it helps to create a negative and aggressive image of Russia. In other words, the study reveals links between a country's ideology and the media coverage of internationally important events all over the world.

Keywords: political media discourse, discourse analysis, contextual analysis, textual analysis, manipulation, coreference.

Research area: philology.

Citation: Kolmogorova, A.V., Gornostaeva, Yu.A. (2016). Media Coverage of Current Political Situation in Ukraine: Discourse Analysis. J. Sib. Fed. Univ. Humanit. soc. sci., 12(1), 89-96. DOI: 10.17516/1997-1370-0031.

\section{Introduction}

Political media discourse is of a great importance today, as its aim is to influence people's minds, manipulate their cognition. Therefore, manipulation is one of the crucial notions of the discourse analysis and is considered as a form of social power

(C) Siberian Federal University. All rights reserved

* Corresponding author E-mail address: yulyatald@yandex.ru; info_ifiyak@sfu-kras.ru

This work is licensed under a Creative Commons Attribution-NonCommercial 4.0 International License (CC BY-NC 4.0). 
abuse, cognitive mind control and discursive interaction (Dijk, 2006). The present study investigates the Western media discourse and the Russian media discourse in terms of current political situation in Ukraine. Thus, the article analyses discursive means of manipulation and is concerned with the interplay between ideology and the way of media coverage.

Political discourse is represented by the genres limited by a social sphere - politics. T.A. van Dijk supposes that a specific example of political action and interaction, political discourse (and its genres) may be singled out as a prominent way of 'doing politics'. Indeed, most political actions (such as passing laws, decision making, meeting, campaigning, etc.) are largely discursive. Thus, besides parliamentary debates, laws, government or ministerial regulations, and other institutional forms of text and talk, there are such political discourse genres as propaganda, political advertising, political speeches, media interviews, political talk shows on TV, party programs, ballots, and so on (Dijk, 1997). There are many studies devoted to the functions of the political discourse. The majority of researchers distinguish the following: persuasive, argumentative, distance, function of group unification, coercion, resistance, opposition, protest, simulation (control over information), legitimization and delegitimization, etc. (Seidel, 1985; Chilton, Schaeffner, 1997; Sheigal, 2000). Many researchers stress that social control is the main objective of communication for addressers of a political text and determines the linguistic means they use (Parshin, 1987). The political discourse is characterized by manipulative feature for the purpose of conducting propaganda and ideological conflict which is done with the help of various linguistic units. Thus, manipulation is a kind of psychological (speech) influence used to achieve a one-sided win by a hidden motive of others to act in a certain manner (Dotsenko, 2000). Political discourse of mass media has a huge impact on formulation of public opinion which is done with the help of the tools of speech manipulation.

\section{Materials and methodology}

The research is based on the theory of T.A. van Dijk's discourse analysis which consists in two steps: contextual analysis and textual analysis (Dijk, 2006). Contexts should be defined in terms of the participants' mental models of communicative events. That is, they are subjective and evaluative representations of self and other participants, and of the other discourse-relevant categories of communicative situations, such as, e.g. (van Dijk 1997a, 1999):

1. overall domain (politics) 
2. overall societal action (legislation)

3. current setting (time, location)

4. current circumstances (bill to be discussed)

5. current interaction (political debate)

6. current discourse genre (speech)

7. the various types of role of the participants (speaker, MP, member of the Conservative Party, white, male, elderly, etc.),

8. the cognitions of the participants (goals, knowledge, beliefs, etc.).

It is said that many genres of political discourse (parliamentary debates, laws, propaganda, slogans, international treaties, peace negotiations, etc.) are largely defined in contextual, rather than in textual terms. Political discourse is not primarily defined by topic or style, but rather by who speaks to whom, as what, on what occasion and with what goals. In other words, political discourse is especially 'political' because of its functions in the political process (van Dijk, 1997b).

In terms of our research we have analyzed 50 articles from western media (the New York Times, the Washington Post, the Daily Mail, and the Daily Telegraph) and 50 articles from Russia Today devoted to the military conflict in Ukraine.

The second step means textual analysis at all the linguistic levels. In the present research we have chosen the lexical level for the analysis. Taken together, this methodology led to deeper understanding of the analyzed discourse and allowed to look at the Ukrainian crisis from different points of view.

\section{Analysis of the material}

According to T.A. van Dijk, contextual analysis supposes determination of the following aspects: circumstances, time, place, event, participants, sphere, participants' role, social relationships between participants, cognitive characteristics of the participants. In this case, we analyze the conflict in Ukraine - military opposition of the self-proclaimed republics, disconnection of Crimea - (event) which has been taking place since May 2014 (time). Political tensions between western countries and Russia - isolation of Russia, sanctions, rejection of the results of referendum in Crimea - (circumstances) are clearly reflected in the media by politicians, journalists and media characters (participants) who assign roles to the participants. In case of the Western media it is probably supposed that Ukraine is a victim, Russia is an aggressor and the USA are the mediator of the conflict. If true, Russian journalists agree that Ukraine is a victim of the conflict, but they believe that the USA are 
an instigator while Russia is a peacemaker. As for cognitive characteristics of the participants which consist of knowledge and ideology, we suppose that Russian government understands that the USA are craving for the growing influence on the European Union, therefore Russian authorities try to prevent it and strive for global dominance, while the USA seek world dominance and try to eliminate Russia's influence denouncing Russian policy. We think that ideologically the USA advocate the democracy and the protection of human rights all over the world while Russia defends its territorial integrity. In the table below we have briefly represented the contextual analysis.

Textual analysis has shown that the same events are described differently by the opponents, so in the table below coreferential pairs of words are represented. Coreference occurs when two or more expressions in a text refer to the same person or thing; they have the same referent (Crystal, 1997: 94).

We suppose that coreference may be considered as a tool of manipulation. For example, Crimea might be named as an 'annexed territory' by western media which tend to deny the results of the referendum and blame Russia in violent intervention. As well as the Crimean peninsula could be mentioned as a "part of Russia" in the Russia Today's articles in order to apply to the historical roots and justify the Russian authorities. According to the Longman Dictionary of Contemporary English, to annex means "to take control of a country or area next to your own, especially by using force". At the same time, self-proclaimed republics - LNR and DNR - are called 'rebel-held', 'rebel-controlled', 'Russia-backed' territories by western journalists to probably stress Russian participation in the civil war in Ukraine, while Russian media tend to stay

Table 1. Contextual analysis of the chosen material

\begin{tabular}{|l|l|}
\hline Circumstances & Political tensions between western countries and Russia \\
\hline Time & May 2014-May 2016 \\
\hline Place & USA / Russia \\
\hline Event, action & Conflict in Ukraine, the joining of Crimea \\
\hline Participants & Russian and western politicians, journalists, media characters \\
\hline Sphere or field & Politics, media \\
\hline Participants' roles & $\begin{array}{l}\text { Ukraine - "victim", Russia - "aggressor", the USA - "the mediator of } \\
\text { the conflict" / Ukraine - "victim", Russia - "peacemaker", the USA - } \\
\text { "instigator" }\end{array}$ \\
\hline $\begin{array}{l}\text { Social relationships } \\
\text { between participants }\end{array}$ & Competing political powers \\
\hline
\end{tabular}


neutral. Rebel is 'someone who opposes or fights against people in authority, someone who refuses to do things in the normal way, or in the way that other people want them to'. In the table 2 we have mentioned the main coreferential pairs found in articles and the lexical meaning of the units.

Interestingly, Ukrainian government and army are represented as 'violent extremist organizations', 'pro-Nazis' or 'fascists' in Russian articles. Needless to say that the topic of fascism is a sore point for all the Russian population, so journalists stress the danger comparing the current situation and terrible Hitlerite Germany.

'Those Nazi groups, the Pravy Sektor [Right Sector] and the Azov Battalion, and all of the rest of these fascist organizations have tremendous sway in Ukraine, they have tremendous fire power behind them' (Russia Today, 28.08.2015).

An Israeli ex-IDF soldier fighting alongside rebels in eastern Ukraine has told the Jerusalem Post that she is battling against 'pro-Nazi activists' who torture and murder civilians and soldiers alike' (Russia Today, 21.08.2015).

Both western and Russian media often chose words with negative connotation to describe each other and use the strategy of negative other-presentation to manipulate the audience. Mass media describe the policy of the opponent as 'aggressive', 'dangerous', 'destructive' etc., declare that authorities try to 'invade', 'attack', 'threaten' etc.

The study reveals links between a country's ideology and the media coverage of internationally important events all over the world. Discursive markers of manipulation correlate with the strategy of the negative other-presentation. Western media present Russia as an aggressor which is going to annex Ukraine, the reverse is true, in that the USA are described as an instigator by the Russia Today. Both parties try to manipulate the audience by condemning the opponent and advocating their 'peacemaking' ideology.

It was noticed that western media use lots of military terms describing the geopolitical situation in Ukraine. We suppose that military terminology helps to show Russia as an aggressor which poses a real threat to the world.

'The current Russian buildup has all the signs of preparation for an offensive. Large, unmarked convoys of heavy weapons and tanks manned by personnel without insignia on their uniforms (like those who took over Crimea) have been seen rumbling toward the front lines in rebel-held territory. Sophisticated artillery and ground-toair missile systems have been moved into position. Units all the way from the east and far north of Russia have been massed. You don't move military units thousands of miles for nothing' (The New York Times, 11.11.2014). 
Table 2. Textual analysis. Coreferential pairs

\begin{tabular}{|c|c|c|}
\hline Western media & Referent & Russia Today \\
\hline $\begin{array}{l}\text { Annexed territory. } \\
\text { To annex - to take control of a country or } \\
\text { area next to your own, especially by using } \\
\text { force }\end{array}$ & Crimea & Part of Russia \\
\hline $\begin{array}{l}\text { Rebel-held, rebel-controlled, rebellious, } \\
\text { Russia-backed territories, self-proclaimed rebel } \\
\text { republics } \\
\text { Rebel - someone who opposes or fights } \\
\text { against people in authority, someone who } \\
\text { refuses to do things in the normal way, or in } \\
\text { the way that other people want them to. }\end{array}$ & LNR, DNR & Novorossia \\
\hline $\begin{array}{l}\text { To annex Crimea, to grab Crimea } \\
\text { To grab: } \\
\text { 1. to take hold of someone or something with } \\
\text { a sudden or violent movement; } \\
\text { 2. to get something for yourself, sometimes } \\
\text { in an unfair way; }\end{array}$ & $\begin{array}{l}\text { The joining } \\
\text { of Crimea }\end{array}$ & $\begin{array}{l}\text { To rejoin country, to belong to Russia, to } \\
\text { identify themselves as Russians, to vote, } \\
\text { to return to Russia } \\
\text { To rejoin - to go back to a group of } \\
\text { people, organization etc. that you were } \\
\text { with before. }\end{array}$ \\
\hline Annexation of Crimea & & Self-determination \\
\hline Ukrainian forces, army & $\begin{array}{l}\text { Ukrainian } \\
\text { army }\end{array}$ & $\begin{array}{l}\text { Violent extremist organization, Nazis, } \\
\text { nationalists, fascists, neo-Nazis, pro- } \\
\text { Nazis, oligarchs } \\
\text { Nazi : } \\
\text { 1. a member of the National Socialist } \\
\text { Party of Adolf Hitler which controlled } \\
\text { Germany from } 1933 \text { to } 1945 \text {; } \\
\text { 2. someone who uses their authority over } \\
\text { others in a very strict or cruel way ; } \\
\text { Neo-Nazi - someone who believes that } \\
\text { white people are better than people } \\
\text { of other races, and who often behaves } \\
\text { violently. } \\
\text { Oligarch - a member of a small group of } \\
\text { people who run a country or organization. } \\
\text { Fascist: } \\
\text { 1. someone who supports fascism; } \\
\text { 2. someone who is cruel and unfair and } \\
\text { does not like people to argue with them; } \\
\text { 3. someone who has extreme right-wing } \\
\text { opinions. }\end{array}$ \\
\hline $\begin{array}{l}\text { Illegal referendum } \\
\text { Illegal - not allowed by the law. }\end{array}$ & $\begin{array}{l}\text { Referendum } \\
\text { in Crimea }\end{array}$ & $\begin{array}{l}\text { Democratic referendum } \\
\text { Democratic: } \\
\text { 1. controlled by representatives who are } \\
\text { elected by the people of a country; } \\
\text { 2. organized according to the principle } \\
\text { that everyone has a right to be involved in } \\
\text { making decisions; } \\
\text { 3. organized according to the principle that } \\
\text { everyone in a society is equally important, } \\
\text { no matter how much money they have or } \\
\text { what social class they come from }\end{array}$ \\
\hline
\end{tabular}


A retired NATO general who recently held talks with the Ukrainian president, Petro Poroshenko, told me that intelligence estimates are of some 45,000 regular Russian troops on the border; tens of thousands of Russian irregulars of various stripes inside Ukraine organized by a smaller number of Russian officers and military personnel; some 450 battle tanks and over 700 pieces of artillery' (The New York Times, 11.11.2014).

\section{Conclusion}

The results seem to suggest that describing the current political situation in Ukraine the mass media use the strategy of negative other-presentation to manipulate the readers' mind. They use specific lexical means to achieve the goal, particularly, words with negative connotation (Table 3). Russian media tend to make parallels between Ukrainian authorities and neo-fascists while western articles are full of military lexicon which might have been used to create an image of Russia as a formidable enemy craving for unleashing the war in Ukraine. At the same time, we have discovered the phenomenon of coreference which occurs when different authors try to put all and the same referents in a favorable or unfavorable light. Thus, the links between a country's ideology and the media coverage of internationally important events all over the world are quite obvious.

\section{References}

Crystal, A. (1997). Dictionary of Linguistics and Phonetics. Cambridge, Blackwell Publishing, $94 \mathrm{p}$.

Chilton, P.A., Schaeffner, C. (1997). Discourse and Politics, In Discourse Studies, 2 , 206-230.

Dijk, T.A. (2006). Discourse and Manipulation, In Discourse and Society, 17 (2), 359-383.

Dijk, T.A. (1997). What is Political Discourse Analysis, In Belgian Journal of Linguistics, 11(1), 11-52.

Dijk, T.A. (2001). Discourse, Ideology and Context, In Folia Linguistica, 35 (1-2), 11-40.

Dijk, T.A. (1999). Context Models in Discourse Processing, In H. van Oostendorp and S.R. Goldman, 123-148.

Dillon, G.L., Doyle, A., Eastman, C.M., Kline, S., Silberstein, S., Toolan, M. (1990). The Rhetorical Construction of a President, In Discourse and Society, 1(2), 189-200. 
Dotsenko, E.L. (1997). Psikhologiia manipuliatsii: fenomeny, mekhanismy $i$ zashchity [Psychology of Manipulation: the Phenomena and Mechanisms of Protection]. Moscow, CheRo, 344 p.

Filinsky, A.A. (2002). Kriticheskii analiz politicheskogo diskursa predvybornykh kampanii [Critical Analysis of the Political Discourse of the Election Campaign]. Tver, $144 \mathrm{p}$.

Graber, D. (1981). Political Languages, In Handbook of Political Communication, 195-224.

Harris, S. (1991). Evasive action: How Politicians Respond to Questions in Political Interviews, In P. Scan-nell (Ed.), 76-99.

Makarov, M.L. (2003). Osnovy teorii diskursa [Fundamentals of the Theory of Discourse]. Moscow, Gnozis, 280 p.

Seidel, G. (1985). Political Discourse Analysis, In Handbook of Discourse Analysis, (4), 43-60.

Seidel, G. (1988). The British New Right's "Enemy Within: The Anti-Racists, In Smitherman-Donaldson \& van Dijk (eds), 131-143.

Sheigal, E.I. (2004). Semiotika politicheskogo diskursa [The Semiotics of Political Discourse]. Moscow, Gnozis, 326 p.

\title{
Освещение в СМИ актуальной политической ситуации на Украине: дискурс-анализ
}

\author{
А.В. Колмогорова, Ю.А. Горностаева \\ Сибирский федеральный университет \\ Россия, 660041, Красноярск, пр. Свободный, 79
}

\begin{abstract}
Исследование посвящено феномену манипуляции в политическом дискурсе и освещению актуальной политической ситуации на Украине в западных (the Washington Post, the Daily Maiil, the New York Times) и российских (the Russia Today) СМИ. Вслед за T.А. ван Дейком был проведен контекстуальный и текстуальный анализ отобранных нами текстов, который показал, что журналисты используют стратегию представления оппонента в невыгодном свете, реализуемую с помощью лексических единиц с негативной коннотацией. Более того, нередко прибегают и к другим средствам манипуляции, например кореференциии.

Ключевые слова: политический медиадискурс, дискурс-анализ, контекстуальный анализ, текстуальный анализ, манипуляция, кореференция.
\end{abstract}

Научная специальность: 10.00.00 - филологические науки. 